\title{
STUDY OF MATERIALS AND WELDING USED IN THE CONSTRUCTION OF RACKS FOR STORAGE OF FUEL ELEMENTS AT NUCLEAR PLANTS
}

\author{
A. A. F. Ribeiro, \\ C. A. M. Ferreira, \\ M. C. L. Souza, \\ and N. C. O. Tapanes \\ Centro Universitário Estadual da Zona Oeste \\ Engineering School \\ Av. Manuel Caldeira de Alvarenga, 1203, Rio \\ de Janeiro - RJ, 23070-200, Brasil \\ carlosferreira@uezo.edu.br \\ Received: Aug 19, 2021 \\ Revised: Aug 30, 2021 \\ Accepted: Sept 02, 2021 \\ ABSTRACT \\ elements

\section{NOMENCLATURE} \\ ASTM - American Society for Testing Materials \\ SMAW - Shielding Metal Arc Welding \\ GTAW - Gas Tungsten Arc Welding \\ ASW - American Welding Society \\ EAS - Classification of Böhler Electrode \\ ASME - American Society of Mechanical \\ Engineering \\ CNEN - National Nuclear Energy Commission.
}

This paper showed the technological innovations and the necessary requirements for the welding of ASTM A240 TP316L Austenitic Stainless Steel in the construction of racks used in the storage of Fuel Elements inside nuclear power plants. It presents the development of welding processes using coated electrode, SMAW and as addition metal rods EAS 2-IG / ER 308L. This study is divided into two stages, the preparation of technical documentation and the development of methods and manufacturing processes used in the qualification of welding processes. A sequence was outlined based on real situations used by nuclear component manufacturing companies, meeting the physical and mechanical properties required by the nuclear classification standards and their regulations. The results showed that the welding processes were satisfactory, that the destructive and nondestructive tests showed that there was no discontinuity in the surface and defects in the volume of the welding and that, in the present study, safety in the project for the operation of a Nuclear Power Plant was demonstrated.

Keywords: welding, shielded metal arc welding, racks, nuclear fuel

\section{INTRODUCTION}

Among the main nuclear components that make up a Nuclear Plant, those belonging to the Primary Circuit stand out, where the radioactive liquid circulates at a temperature of $280^{\circ} \mathrm{C}$. This heat is generated by the phenomenon of Nuclear Fission that occurs in the reactor core. This liquid is transformed into superheated steam used in the turbine blades, causing a uniform circular movement in the axis of the electric generator.

The nuclear components include the Nuclear Reactor and its Internals (fuel elements, uranium pellets, etc.), the Steam Generators, the Pressurizer and the Borated Water Pool with high capacity to neutralize radioactivity, due to the absorption of neutrons contained in Boron (CODERRE, 2008). In this, the fuel elements are stored in stainless steel crates, called Racks, whose removals from the interior of the Nuclear Reactor are moments of high subcriticality, subject to strict safety standards.
The aim of this research is to develop the qualification of the welding of this Austenitic Stainless Steel, class ASTM A240 TP316L, verifying the influence of welding processes with coated electrode, SMAW -"Shielded Metal Arc Welding" and with welding rod, GTAW - Gas Tungsten Arc Welding (CASTRO, 2011), in the microstructural properties of the material, through tests and Destructive and Non-Destructive Tests in the metallographic structure of the base material of the Racks, presenting a practical content on how the procedures and production sequences are performed within of a state-of-the-art factory.

\section{MATERIAL AND METHODS}

\section{Material}

The qualification of Austenitic Stainless Steel welding for nuclear components involves the production of a Test Body, Welding Procedure Qualification (WPQ) simulating the welded joint, which must be performed with the same characteristics as the joint between the parts to be welded in the nuclear component.

\section{Base metal}

To perform the WPQ, 03 (three) samples were used with the base metal Austenitic Stainless Steel ASTM A240 TP316L, and their technical characteristics were verified, through a Receipt Inspection of the raw material, with the receipt 
control registered in the Receipt Inspection Report with the results shows in Tables 1 and 2:

Table 1. Maximum Chemical Composition of Base Metal Grade 316L - ACESITA Certificate.

\begin{tabular}{|c|c|c|c|c|c|c|c|c|c|}
\hline $\mathbf{C}$ & $\mathbf{M n}$ & $\mathbf{S i}$ & $\mathbf{P}$ & $\mathbf{S}$ & $\mathbf{C r}$ & $\mathbf{N i}$ & $\mathbf{M o}$ & $\mathbf{A l}$ & $\mathbf{C u}$ \\
\hline 0,02 & 1,37 & 0,45 & 0,04 & 0,005 & 17,1 & 11,09 & 2,01 & 0,015 & 0,14 \\
\hline
\end{tabular}

Table 2. Mechanical properties of Base Metal ACESITA Certificate

\begin{tabular}{|l|c|}
\hline Tensile strength & $604 \mathrm{MPa}$ \\
\hline Elastic Limit & $301 \mathrm{MPa}$ \\
\hline Elongation & $60 \%(50 \mathrm{~mm})$ \\
\hline Hardness (max.) & $68 \mathrm{RB}$ \\
\hline
\end{tabular}

Each of the samples is divided into two halves with dimensions of $200 \mathrm{~mm} \times 455 \mathrm{~mm}$, with a thickness of $12.5 \mathrm{~mm}$, according to the number of specimens to be made in each sample

\section{Filler metal}

The filler metal used for welding the joints between the base materials was the Bhöler EAS 2-IG / ER 308L welding rod, classification E308L-17, in the root welding SD1, Figure 1, selected according to the recommendations of AWS A5.9 (CASTNER, 2010).

This rod has good corrosion resistance, with a low carbon content, which makes this alloy recommended against the risk of intergranular corrosion, as in cases of work at high temperatures, not exceeding $350^{\circ} \mathrm{C}$. This alloy is widely used in chemical, nuclear, food, boiler piping and stainless steel joints with a maximum $\mathrm{Cr}$ of $18 \%, \mathrm{Ni}$ greater than $8 \%$ and low carbon content. See the chemical compositions and resistances described in Tables 3 and 4.

Table 3. Chemical Composition of Rod Böhler EAS 2-IG / E308L

\begin{tabular}{|c|c|c|c|c|c|c|c|c|}
\hline $\mathrm{C}$ & $\mathrm{Mn}$ & $\mathrm{Si}$ & $\mathrm{Ni}$ & $\mathrm{Cr}$ & $\mathrm{Mo}$ & $\mathrm{Cu}$ & $\mathrm{N}$ & Ferrite \\
\hline 0,08 & 7,0 & 0,90 & 8,10 & 18,7 & 0,2 & 0,15 & 0,05 & 9 \\
\hline
\end{tabular}

Table 4. Mechanical properties of rod Böhler EAS 2A / ER308L

\begin{tabular}{|l|c|}
\hline Tensile strength & $280 \mathrm{MPa}$ \\
\hline Elastic Limit & $610 \mathrm{Mpa}$ \\
\hline Elongation & $36 \%$ \\
\hline
\end{tabular}

To performance of the SD2 chamfer filler welding (See Figure 1) the addition material established by the AWS A5.4 standard was the coated electrode Böhler FOX EAS 2-A / 308L-17. This electrode is composed of chromium-nickel wire, with good corrosion resistance. Its alloy has a low carbon content, which makes it particularly recommended when there is a risk of intergranular corrosion. It has a coating optimized for welding in vertical upward positions, $3 \mathrm{~g}$, flat, $2 \mathrm{~g}$ and overhead, $4 \mathrm{~g}$, in austenitic stainless steels. This filler metal alloy is also widely used in the chemical, nuclear and food processing industries, as well as in pipes, tubes and boilers, with working temperatures not exceeding $350{ }^{\circ} \mathrm{C}$, and also for joining steel stainless steel with a maximum $\mathrm{Cr}$ of $18 \%$ and $\mathrm{Ni}$ greater than $8 \%$, according to the chemical compositions and mechanical strengths described in Tables 5 and 6.

Table 5. Chemical Composition of Rod Böhler EAS 2-IG / E308L

\begin{tabular}{|c|c|c|c|c|c|c|}
\hline Grade & $\mathrm{C}$ & $\mathrm{Si}$ & $\mathrm{Mn}$ & $\mathrm{Cr}$ & $\mathrm{Mo}$ & $\mathrm{Ni}$ \\
\hline ER308L & 0,03 & 0,90 & 0,80 & 19,30 & - & 10,0 \\
\hline
\end{tabular}

Table 6. Mechanical properties of rod Böhler EAS 2A / ER308L

\begin{tabular}{|l|c|}
\hline Tensile strength & $580 \mathrm{MPa}$ \\
\hline Elastic Limit & $430 \mathrm{Mpa}$ \\
\hline Elongation & $45 \%$ \\
\hline
\end{tabular}

\section{Sample Preparation}

Samples and tests for WPQ must be manufactured in accordance with the requirements established in the nuclear construction plans, and manufacturing standards and welding procedures qualification in the GTAW / SMAW processes, P8G1 group, according to the following standards and regulations.

1) Standards of Section IX of the ASME VIII Code (ASME, 2014);

2) Boiler and Pressure Vessel Code, 2010 Edition;

3) Section II, Part A, specification AS-240 and Section II, Part C;

4) SFA-5.9 specifications;

5) ASTM (American Society for Testing and Materials), A 262; A370;

6) KTA Standards (Kern Technische Ausschuss) 11408 (2015 edition);

7) AWS (American Welding Society), A4.2;

8) Regulations and standardization of the ASME III Code;

9) Welding Requirements Technical Instructions; Receipt of materials; Receipt of Consumables; Radiographic Tests, Visual Testing Procedures; Penetrant Liquid Tests; Marking and preparation of specimens, all prepared by the manufacturer, based on the technical specifications of the ASME III Code and on the Customer's operating specifications, approved by the Independent Inspection Agency. 


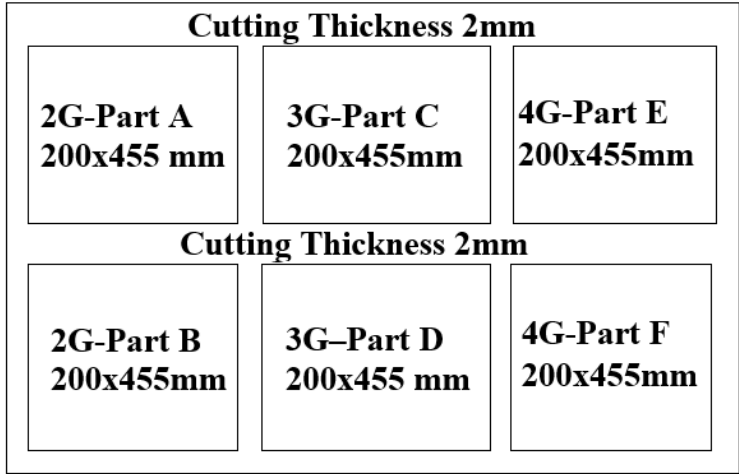

Figure 1. Cutting Plan - CP, samples for procedure qualification.

Figure 2 shows the Cutting Plan of the six pieces that make up the three samples of Austenitic Stainless Steel ASTM A240 TP316L, with 1/2" thick and dimensions of $200 \mathrm{~mm}$ wide by $455 \mathrm{~mm}$ in length, obtained by the Plasma cutting process and the geometry of the weld bevel.

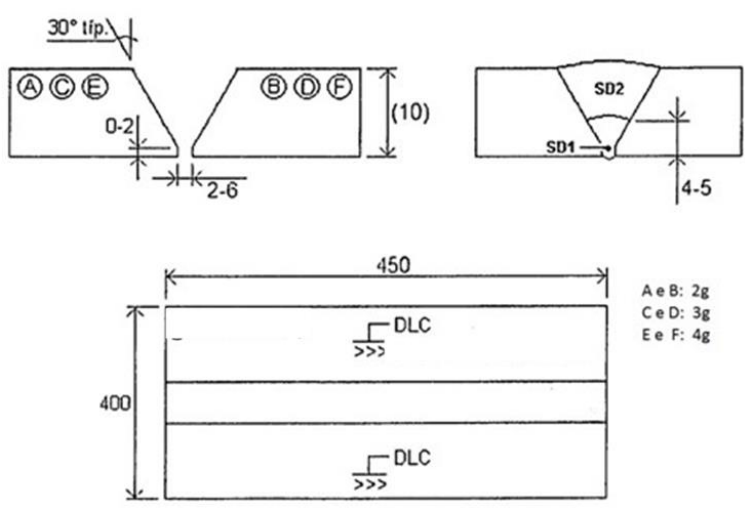

Figure 2. Test specimen of WPQ - SD1 root and SD2 filling.

\section{Sample Welding}

The assembly of the joints to be welded, with regard to the chamfer opening and other welding parameters, was carried out according to the guidelines contained in the Welding Plan and the relevant standards and codes, as shown in Table 7.

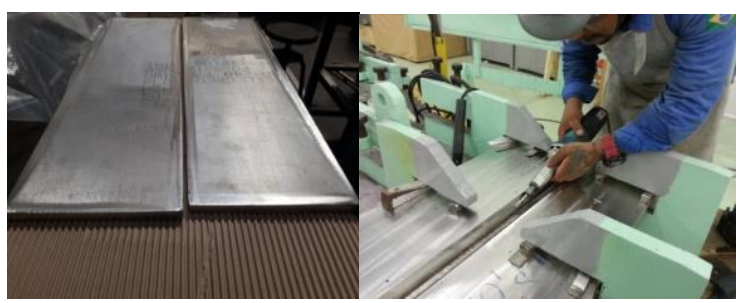

Figure 3. Cutting of Sample Sheets and Preparation for Welding.
Table 7. Welding Plan - WP, according to the Parameters required by the standards.

\begin{tabular}{|c|c|c|}
\hline PARAMETERS & GTAW & SMAW \\
\hline $\begin{array}{l}\text { Deposition sequence } \\
\text { (Figure 3) }\end{array}$ & SD1 & SD2 \\
\hline \multicolumn{3}{|l|}{ FILLER METAL: } \\
\hline Manufacturer & $\begin{array}{c}\text { EAS 2-IG / ER } \\
\text { 308L }\end{array}$ & \begin{tabular}{|c|} 
FOX EAS 2-A \\
$/ 308 \mathrm{~L}-17$
\end{tabular} \\
\hline Commercial name: & Bhöler & Bhöler \\
\hline Diameter & $1,6-2,4$ & $2,5-4,0$ \\
\hline Specification & SFA-5.9 & SFA-5.4 \\
\hline AWS classification & ER308L & E308L-17 \\
\hline Product type & Solid wire & $\begin{array}{l}\text { Coated } \\
\text { electrode }\end{array}$ \\
\hline $\begin{array}{l}\text { Thickness of } \\
\text { deposited metal }\end{array}$ & $4-5$ & $7-8$ \\
\hline Weld Positions & see Figure 3 & see Figure 3 \\
\hline Progression & Ascendant & Ascendant \\
\hline Minimum preheat $\left({ }^{\circ} \mathrm{C}\right)$ & $20^{\circ}$ & $20^{\circ}$ \\
\hline Enter maximum pass & $150^{\circ} \mathrm{C}$ & $150^{\circ} \mathrm{C}$ \\
\hline Heat treatment & Not necessary & Not necessary \\
\hline Shielding gas & $\mathrm{Ar} \geq 99,9 / 10-16$ & - \\
\hline Purge gas & $\mathrm{Ar} \geq 99,9 / 7-20^{1}$ & - \\
\hline Heat input $(\mathrm{kJ} / \mathrm{cm})$ & $\leq 15\left({ }^{2}\right)$ & $\leq 15\left({ }^{2}\right)$ \\
\hline Current and polarity & $\mathrm{CC}-$ & $\mathrm{CC}+$ \\
\hline Amperage & $(3)$ & $(3)$ \\
\hline Voltage & $10-16(3)$ & $20-30$ \\
\hline Welding speed & $(3)$ & $(3)$ \\
\hline $\begin{array}{l}\text { Tungsten electrode } \\
\text { (SFA-5-12) }\end{array}$ & EWTh-2 & - \\
\hline $\begin{array}{l}\text { Diam. tungsten } \\
\text { electrode }\end{array}$ & 2,4 or $3,2 \mathrm{~mm}$ & - \\
\hline \multicolumn{3}{|l|}{ TECHNIQUE: } \\
\hline Type cord & $\begin{array}{l}\text { Straight or } \\
\text { braided }\end{array}$ & $\begin{array}{c}\text { Straight or } \\
\text { braided }\end{array}$ \\
\hline $\begin{array}{l}\text { Internal Diam Gas } \\
\text { Nozzle }\end{array}$ & $8-12 \mathrm{~mm}$ & \\
\hline Cleaning method & Brush, grind $\left({ }^{4}\right)$ & Brush, grind $\left({ }^{4}\right)$ \\
\hline Excavation method & Machining & Machining \\
\hline Multiple passes & Multiples & Multiples \\
\hline $\begin{array}{l}\text { Single or multiple } \\
\text { electrode }\end{array}$ & Simple & Simple \\
\hline Performing & Manual & Manual \\
\hline \multicolumn{3}{|c|}{$\begin{array}{l}\left({ }^{1}\right) \text { Keep the purge until complete deposition of the first } \\
\text { layer of SD2(SMAW) } \\
\text { (2) Non-essential variable, for reference only } \\
\left({ }^{3}\right) \text { Values of A and V to choose the welding speed, } \\
\text { depending on the input } \\
\left({ }^{4}\right) \text { Brush austenitic stainless steel only. Aluminum } \\
\text { Oxide Grinder, Iron Free }\end{array}$} \\
\hline
\end{tabular}


Table 8. Amperage as a function of welding speeds.

\begin{tabular}{|c|c|c|c|}
\hline \multicolumn{2}{|c|}{ SMAW $\varnothing 2,5 \mathrm{~mm}$} & \multicolumn{2}{c|}{ SMAW $\varnothing 3,2 \mathrm{~mm}$} \\
\hline $\mathrm{A}$ & $\mathrm{S}^{*}$ & $\mathrm{~A}$ & $\mathrm{~S}^{*}$ \\
\hline $60-70$ & 8,4 & $80-90$ & 10,8 \\
\hline $70-80$ & 9,6 & $90-100$ & 12,0 \\
\hline $80-90$ & 10,8 & $100-110$ & 13,2 \\
\hline $90-100$ & 12,0 & $110-120$ & 14,4 \\
\hline SMAW $\varnothing$ & $4,0 \mathrm{~mm}$ & \multicolumn{2}{|c|}{ GTAW } \\
\hline A & $\mathrm{S}^{*}$ & $\mathrm{~A}$ & $\mathrm{~S}^{*}$ \\
\hline $110-120$ & 14,4 & $60-90$ & 5,8 \\
\hline $120-130$ & 15,6 & $90-110$ & 7,0 \\
\hline $130-140$ & 16,8 & $110-130$ & 8,5 \\
\hline $140-150$ & 18,0 & $130-150$ & 9,5 \\
\hline & & $150-180$ & 11,5 \\
\hline & & $180-210$ & 13,4 \\
\hline
\end{tabular}

* Speed $\min (\mathrm{cm} / \mathrm{min})$

Obtaining the test values provided for in the standards starts with the quality of the welding equipment and the proper preparation of the assembly and machining of the geometry of the chamfers of the samples (RIBEIRO, 2019), as shown in Figures 4 and 5

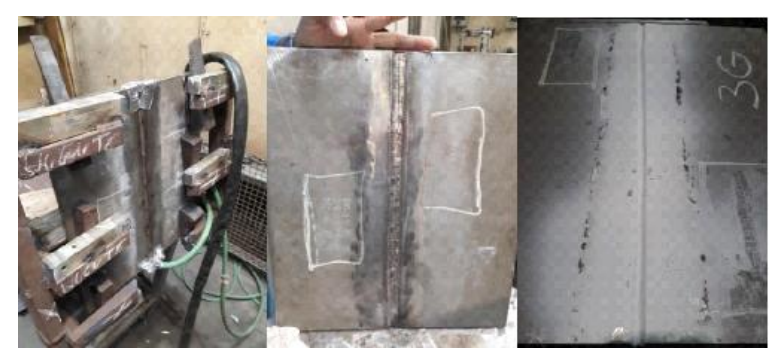

Figure 4. Welding of samples used for the removal of specimens of WPQ.

The deposition sequence of the beads was defined aiming to take advantage of the temperature of the bead deposited superimposedly and immediately on the previous bead, applying a tempering in the filler material in order to correct the tenacity and excessive hardness, achieving, with this, an increase in the toughness of the weld joint.

\section{Methodology}

NON-DESTRUCTIVE TESTING:

a. VT (Visual Test) chamfer ends assembly and welding;

b. DT (Dimensional Test) plate ends, assembly and welding;

c. PT (Penetrating Liquid) penetrating liquid for chamfers and welds;

d. RT (Radiography Test) - X-ray on $100 \%$ of the welded joint;

\section{DESTRUCTIVE TESTS:}

a. VT / DT / PT before and after cutting the specimens; b. Metallography, Macrography and Micrography in the solder volume;

c. Delta ferrite in solder volume

d. Transverse Traction and folding of the 3 specimens;

e. Intercrystalline Corrosion;

Figures 6, 7 and 8 shows the specimens and their preparations to be submitted to the tests perform.

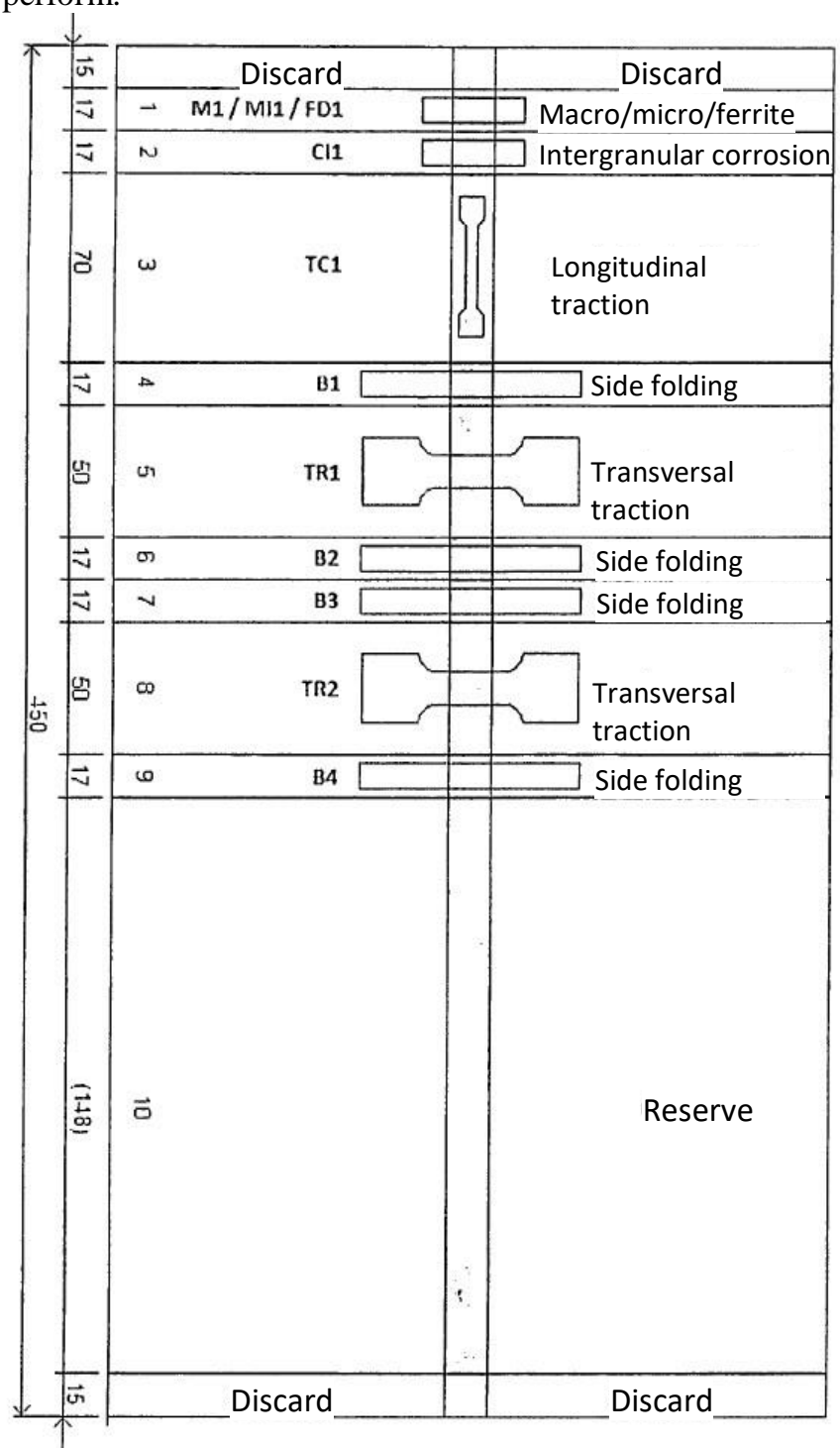

Figure 6 - Layout of specimens (mm)
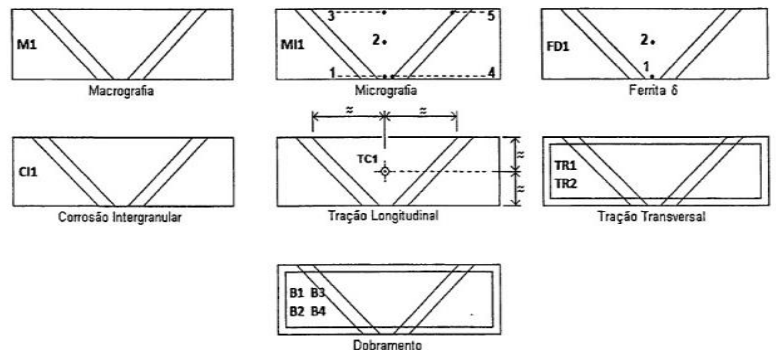

Figure 7 - Location of Metallographic specimens 


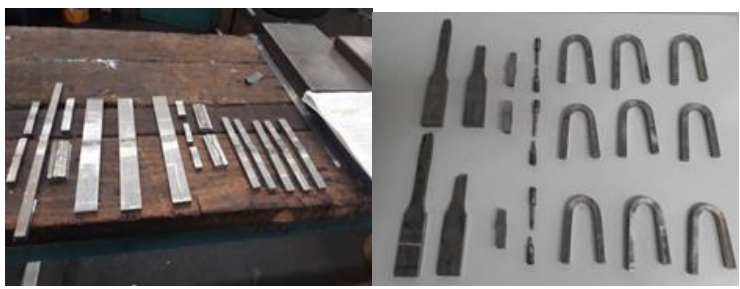

Figure 8 - Machining of specimens, specimens of traction and folding

\section{RESULTS AND DISCUSSION}

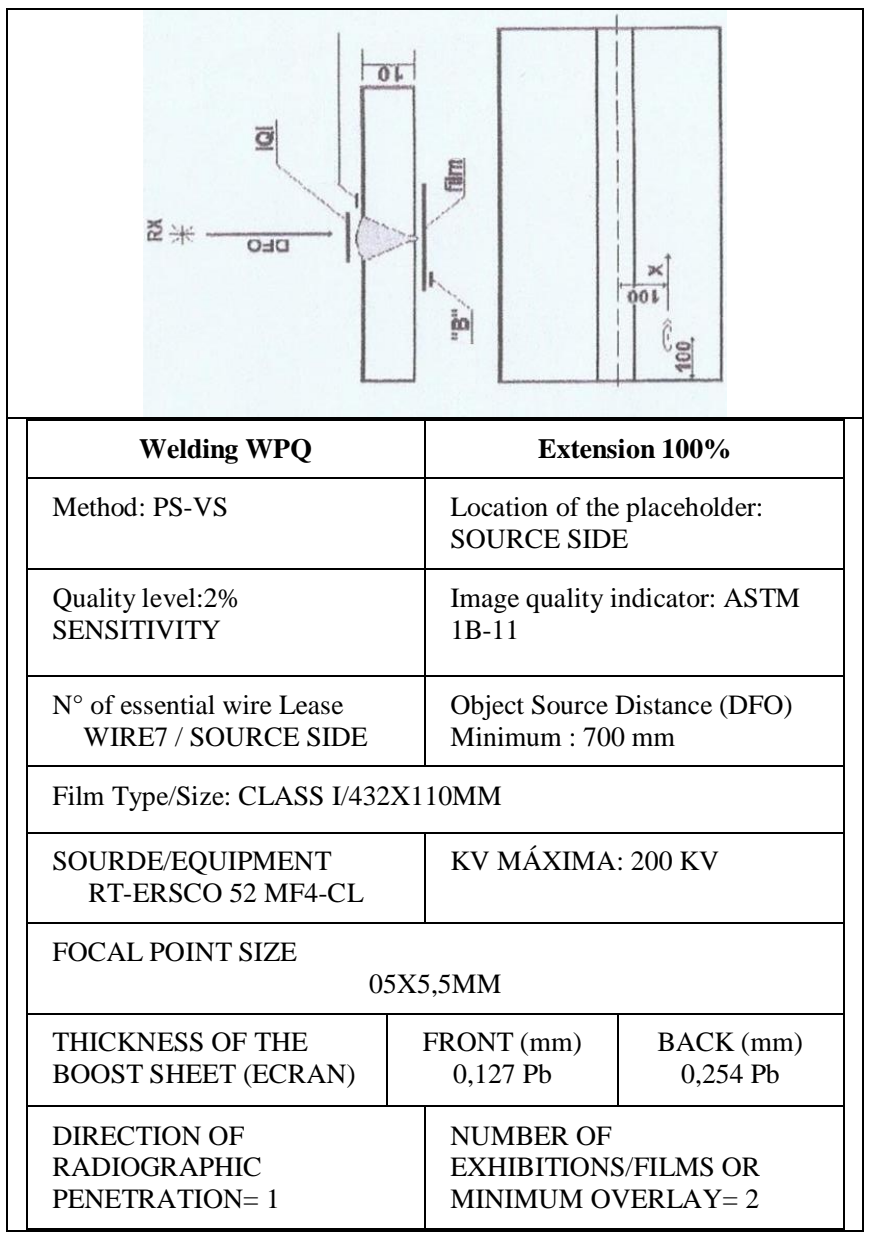

Figure 9 - Radiography Test. The three welded joints were "Approved".

After performing the tests, such as Penetrant Liquid (LP), Visual (VT); Transverse Traction; Folding; Macrograph and Micrograph; Intercrystalline Corrosion; Ferrite Delta and, in particular, the X-Ray Ferrite (RT) detailed in Figure 9, all samples had their results approved according to the criteria established by CNEN 1.16 and Section 10 of the ASME IX Code:

The Metallographic tests were composed with macrographs, micrographs, delta ferrite and intercrystalline corrosion test, with $200 \mathrm{x}$ magnification, without surface discontinuities and adequate penetration, according to Figures 11 to 12:

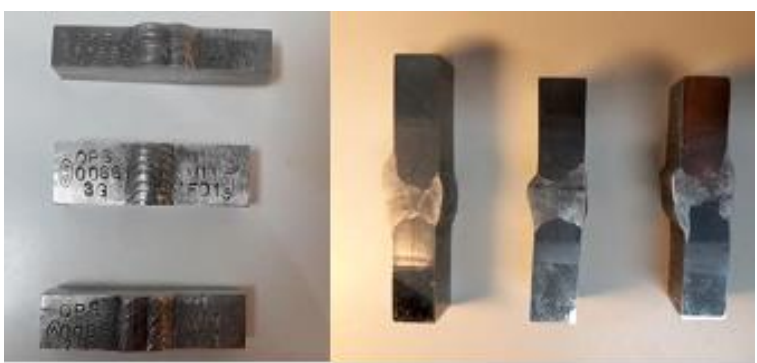

Figure 10 - Macrograph of samples A-B C-D and E$\mathrm{F}$, respectively
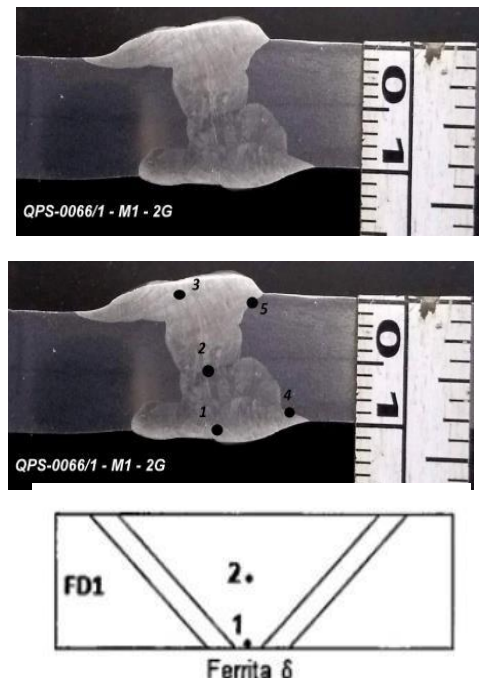

Figure 11 - Sample MI1-2g - Metallographic test, transversal section with micrograph locations and Ferrite Delta. AWS A4. Value: FN $\geq 5$. Point 1: 5.6FN; Point 2: 5.5FN.
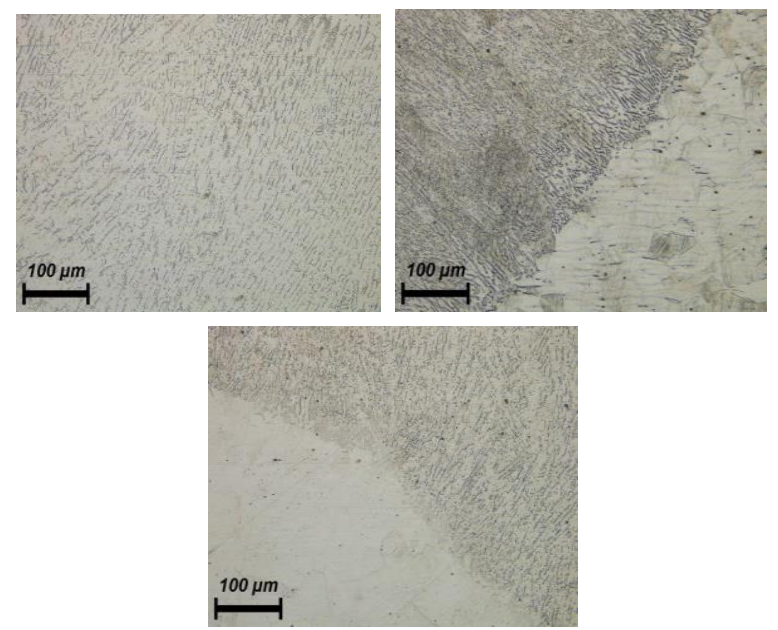

Figure 12 - Delta ferrite in austenitic matrix. 200x magnification. FISHER FMP30C FERRITOSCOPE Standards N1-1024 FGAB1.3-FE 


\section{CONCLUSIONS}

At the end of the development of welding procedure, it is concluded that all samples showed satisfactory results in destructive and non-destructive tests, without surface discontinuities or defects in the weld volume, demonstrating that the criteria established in the choice of welding parameters, machines and equipment, operational processes adopted and in the preparation of tests contributed to the approval of the use of Austenitic Stainless Steel ASTM A240 TP316L and its consumables, in the welding of nuclear components belonging to the Primary Circuit of Nuclear Power Plants.

The values of the Transverse Traction tests (according to ASTM A370), obtained with 35\% above the Resistance Limit, as well as the Folding and mechanographic tests without any discontinuity in all specimens, demonstrate full compliance with the minimum requirements established by the standards and technical specifications of the builders of generating core installations.

\section{ACKNOWLEDGEMENTS}

The authors would like to thank the financial support given by the Research Support Foundation of the State of Rio de Janeiro (FAPERJ) to the study.

\section{REFERENCES}

AMERICAN SOCIETY OF MECHANICAL ENGINEERS - ASME, BPVC Boiler and Pressure Vessel Committee, Specification for P-Numbers Group for Stainless Steel QW/QB-422 Ferrous/Nonferrous Base metal qualification (SA210). In: Section IX and III,2010. AWS 5.5 Specification for Alloy Stell Electrodes for Shielded Metal Arc Welding, 2014.

CASTNER, H. R. "What You Should Know About Austenitic Stainless. Steel". Welding Journal vol. 72, n. 4, pag. 53-59, 2010.

CASTRO, R. e CADENET, J. J., "Welding Metallurgy of Stainless and Heat. Resisting Steels". 1 ed. Cambridge, England, Cambridge University, 2011.

CODERRE J. Derivation of the radiation produced during boron neutron capture irradiation, Intl J Radiat Biol Phys; vol. 27; pag. 1121-1129, 2008.

RIBEIRO, A. A. F., Desenvolvimento da Soldagem do Aço Inoxidável Austenítico ASTM A 240 TP 316L para Uso em Internos de Reatores Nucleares pelos Processo de Sodagem Com Eletrodo Revestido e TIG. Dissertação de Mestrado em Ciência e Tecnologia de Materiais - UEZO, 2019. 